\title{
SEMINAR IDENTIFIKASI BAKTERI ESCHERICHIA COLI 0157:H7 PADA FESES PENDERITA DIARE DENGAN METODE KULTUR DAN PCR
}

\author{
Vincentia Ade Rizky ${ }^{1}{ }^{*}$, Sa'adah Siregar ${ }^{1}$, Visensius Krisdianilo ${ }^{1}$, Asvia Rahayu ${ }^{1}$ \\ ${ }^{1}$ Program Studi Teknologi Laboratorium Medik, Institut Kesehatan Medistra Lubuk Pakam \\ Jln. Sudirman No.38 Lubuk Pakam, Kabupaten Deli Serdang, \\ Sumatera Utara - Indonesia \\ *email korespondensi author: vincentiarizky@gmail.com
}

DOI $10.35451 /$ jpk.v1i1.746

\begin{abstract}
Abstrak
Infeksi merupakan penyebab utama penyakit di dunia terutama di daerah tropis, seperti Indonesia. Agen penyebab infeksi antara lain bakteri Escherichia coli. Bakteri Escherichia coli O157:H7 merupakan penyebab utama foodborne disease di beberapa negara. Penyakit diare masih menjadi masalah utama di Indonesia yang perlu penanganan dan kajian dari berbagai aspek. Pemeriksaan laboratorium metode konvensional seperti kultur merupakan metode yang sering dilakukan, akan tetapi dalam menegakan diagnosa membutuhkan waktu yang lama, jumlah sampel yang banyak, dan hasil kurang akurat karena dapat terjadi kontaminasi. Teknik identifikasi bakteri Escherichia coli 0157:H7 dalam feses penderita diare dengan menggunakan metode molekuler yaitu PCR sudah terbukti lebih sensitif dan menunjukkan hasil yang cepat namun dengan biaya yang mahal jika dibandingkan dengan metode konvensional. Oleh karena itu dapat direkomendasikan dan digunakan oleh tenaga kesehatan dalam mendeteksi dini sehingga akan membantu penegakan diagnosa lebih cepat dan menentukan pengobatan secara lebih efektif. Hasil seminar ini bertujuan agar petugas laboratorium lebih mudah dalam mengidentifikasi bakteri Escherichia coli 0157:H7 pada penderita diare.
\end{abstract}

Kata Kunci: Escherichia coli O157:H7, PCR, Kultur

\begin{abstract}
Infection is the main cause of disease in the world, especially in tropical areas, such as Indonesia. The causative agents of infection include Escherichia coli bacteria. Escherichia coli 0157:H7 is the main cause of foodborne disease in several countries. Diarrhea is still a major problem in Indonesia that needs to be handled and studied from various aspects. Conventional laboratory examination methods such as culture are methods that are often used, but establishing a diagnosis requires a long time, large number of samples, and less accurate results because contamination can occur. The technique of identifying Escherichia coli 0157:H7 bacteria in the feces of diarrhea sufferers using the molecular method, namely $P C R$, has been proven to be more sensitive and shows fast results but is expensive when compared to conventional methods. Therefore, it can be recommended and used by health workers in early detection so that it will help diagnose faster and determine treatment more effectively. The results of this seminar are intended to make it easier for laboratory workers to identify Escherichia coli 0157:H7 bacteria in diarrhea sufferers.
\end{abstract}

Keywords: Escherichia coli O157:H7, PCR, Culture 
Received: 16 June 2021 :: Accepted: 25June 2021 :: Accepted: 30 June 2021

\section{Pendahuluan}

Penyakit yang sering terjadi di daerah tropis terutama di Indonesia adalah Infeksi. Infeksi dapat disebabkan oleh bakteri, virus, dan lain sebagainya. Namun yang sering terjadi penyebab infeksi adalah bakteri seperti Escherichia coli. (Hermayudi \& Ayu, 2017). Escherichia coli merupakan bakteri komensal atau flora normal di peritoneum atau usus bagian bawah (Elliott et al., 2013). Escherichia coli akan bersifat patogen apabila berada ditempat yang bukan habitatnya yaitu jaringan di luar intestinal yang normal (Brooks et al., 2005).

Bakteri Escherichia coli dapat mengeluarkan racun sehingga menjadi patogen dan menyebabkan penyakit. Bakteri yang memproduksi racun ini disebut Shiga Toxinproducing Escherichia coli (STEC) dan sering teridentifikasi adalah bakteri Escherichia coli O157:H7. (Jawetz et al., 2010; Rananda et al., 2016).

E. coli O157:H7 merupakan penyebab utama foodborne disease di beberapa negara. Laporan Centers for Disease Control (CDC) dari tahun 19822002 mengenai insiden infeksi Escherichia coli O157:H7. Terdapat 49 negara bagian di AS melaporkan 8.598 kasus akibat bakteri ini diantaranya sejumlah 1.493 (17\%) masuk RS, 254 (4\%) teridentifikasi HUS, dan 40 $(0,5 \%)$ meninggal. $\mathrm{Di}$ Indonesia, penelitian mengenai bakteri $E$. coli O157:H7 telah dilakukan oleh Sartika et al., (2005) menyatakan bahwa daging sapi menunjukkan hasil positif $100 \%$ dan $73 \%$ susu sapi terkontaminasi Escherichia coli O157:H7 (Rananda et al., 2016). Hasil penelitian juga menunjukkan bahwa kontaminasi bakteri ini disebabkan karena adanya kontak langsung dengan hewan infektif ataupun kontaminasi makanan (sayur, buah air, susu) (Sartika et al., 2005).

Infeksi dari bakteri E.coli dengan serotype 0157:H7 dapat menimbulkan gejala seperti diare dengan atau tanpa darah maupun asimptomatis (Dutta et al., 2011; Peter et al., 2011). Penyakit Diare sering menjadi masalah setiap manusia terutama di Indonesi namun terkadang masih disepelekan, maka dari itu perlu kajian dan penanganan yang tepat. Salah satu pemeriksaan yang digunakan dalam menganalisa penyebab diare adalah pemeriksaan laboratorium. Pemeriksaan lab metode konvensional seperti kultur merupakan metode yang sering dilakukan, akan tetapi dalam menegakan diagnosa membutuhkan waktu yang lama, jumlah sampel yang banyak, dan hasil kurang akurat karena dapat terjadi kontaminasi. Teknik lain yang lebih akurat untuk mendeteksi Escherichia coli 0157:H7 adalah dengan teknik PCR.

Penelitian sebelumnya Bakri et al., (2010) menunjukkan bahwa dari 28 sampel feses anak berumur 0-14 tahun yang didiagnosis diare diperoleh 6 sampel positif $(21,42 \%)$ Escherchia coli O157:H7 dengan metode kultur dan 13 sampel $(46,43 \%)$ positif bakteri Escherchia coli 0157:H7 dengan metode PCR.

Seminar ini bertujuan untuk mensosialisasikan dan memberikan wawasan kepada petugas laboratorium agar dapat mengidentifikasi bakteri Escherichia coli serotiper 0157:H7 penyebab penyakit diare. Dimana sejauh ini banyak petugas laboratorium yang masih menggunakan metode konvensional atau metode kultur. Kedua metode ini sama-sama mampu mendeteksi bakteri Escherichia coli 0157:H7, hanya saja metode PCR lebih sensitive dan cepat dibandingkan dengan metode kultur. Kontaminasi pada metode PCR relative lebih kecil dibandingkan dengan metode kultur.

\section{Metode}

Kegiatan pengabdian ini dilakukan melalui seminar menggunakan metode ceramah, tanya jawab dan demonstrasi. Untuk mengidentifikasi bakteri Escherichia coli serotype 0157: $\mathrm{H} 7$ menggunakan metode kultur dan PCR

Prosedur yang digunakan dalam kegiatan pengabdian ini adalah sebagai berikut:

\section{Tahap persiapan}

Mempersiapkan materi sosialisasi dan media pendukungnya seperti leaflet. Alat dan bahan yang digunakan 
Received: 16 June 2021 :: Accepted: 25June 2021 :: Accepted: 30 June 2021

dalam identifikasi Escherichia coli 0157:H7 secara kultur dan PCR, disuguhkan dalam materi sosialisasi berupa PPT.

2. Tahap Pelaksanaan Kegiatan

Sosialisasi mengenai identifikasi bakteri Escherichia coli 0157:H7 metode kultur dan PCR terhadap peserta melalui kegiatan seminar. Sosialisasi ini diharapkan dapat membuka dan menambah wawasan para peserta petugas laboratorium.

\section{Hasil dan Pembahasan}

Hasil identifikasi pada sampel feses pemeriksaan kultur ditunjukkan pada tabel 1.

Tabel 1. Zona Hambat Uji Antibakteri

\begin{tabular}{|c|c|c|c|c|c|c|}
\hline \multirow[b]{2}{*}{$\begin{array}{c}\text { Samp } \\
\text { el }\end{array}$} & \multirow[b]{2}{*}{ Mikroskopis } & \multirow[b]{2}{*}{$\begin{array}{l}\text { Sorbitol Mac } \\
\text { Conkey Agar }\end{array}$} & \multicolumn{4}{|c|}{ Uji Biokimia } \\
\hline & & & Indol & $\begin{array}{c}\text { Methyl } \\
\text { Red (MR) }\end{array}$ & $\begin{array}{c}\text { Voges } \\
\text { Proskaue } \\
\text { r (VP) }\end{array}$ & $\begin{array}{c}\text { Simon's } \\
\text { Citrate }\end{array}$ \\
\hline F3 & Gram (-) Bacil (+) & $\begin{array}{c}\text { Jernih (Tidak } \\
\text { Berwarna) }\end{array}$ & + & + & - & - \\
\hline F5 & Gram (-) Bacil (+) & $\begin{array}{c}\text { Jernih (Tidak } \\
\text { Berwarna) }\end{array}$ & + & + & - & - \\
\hline F6 & Gram (-) Bacil (+) & $\begin{array}{c}\text { Berwarna Merah } \\
\text { Muda }\end{array}$ & - & - & + & + \\
\hline F9 & Gram (-) Bacil (+) & $\begin{array}{c}\text { Berwarna Merah } \\
\text { Muda }\end{array}$ & + & + & - & - \\
\hline
\end{tabular}

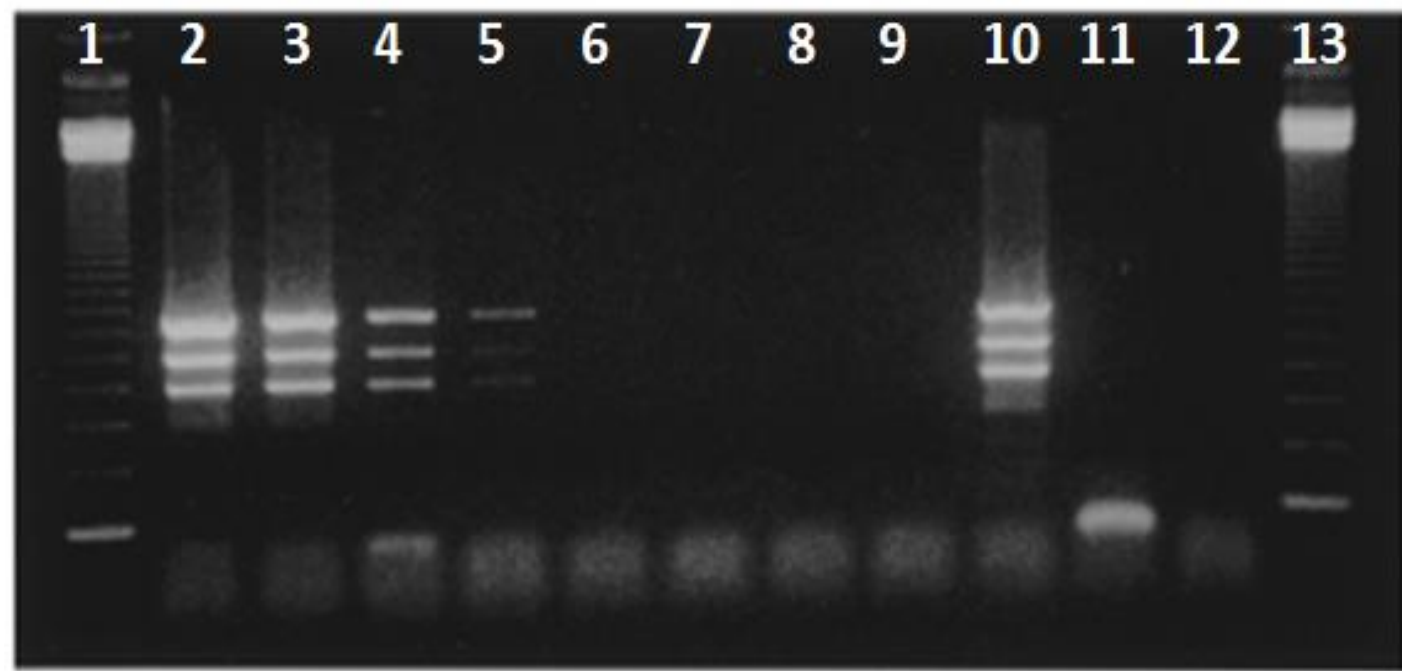

Gambar 1 Hasil Pemeriksaan Elektroforesis yang menunjukkan amplifikasi DNA multipleks PCR yang telah diekstraksi, secara berurut: Jalur $1 \& 13$ Marker DNA 123 bp; Jalur 2-9 Sampel; Jalur 10 Positif kontrol strain Escherichia coli O157:H7; Jalur 11 Negatif kontrol Escherichia coli ATCC 25922.

Hasil uji PCR pada pita fragmen dengan ukuran 123 bp menunjukkan bahwa sampel F2,F3,F4 dan F5 terdapat bakteri Escherichia coli
O157:H7, sedangkan pada sampel yang lain tidak ditemukan bakteri Escherichia coli 0157:07 (Gambar $1)$. 
Received: 16 June 2021 :: Accepted: 25June 2021 :: Accepted: 30 June 2021

Hasil yang diperoleh dari kegiatan pengabdian ini adalah sebagai berikut:

1. Materi seminar dapat dipahami oleh peserta seminar yaitu petugas laboratorium.

2. Peserta seminar dapat menerapkan identifikasi bakteri penyebab penyakit diare melalui pemeriksaan PCR.

3. Peserta seminar mendapat wawasan bahwasannya identifikasi PCR lebih sensitive dan cepat dibandingkan kultur.

\section{Kesimpulan}

Berdasarkan hasil penelitian yang telah dilakukan dan dibandingkan dengan penelitian lain dapat disimpulkan bahwa teknik identifikasi bakteri Escherichia coli 0157:H7 dalam feses penderita diare dengan menggunakan metode molekuler yaitu PCR sudah terbukti lebih sensitif dan menunjukkan hasil yang cepat namun dengan biaya yang mahal jika dibandingkan dengan metode konvensional. Oleh karena itu dapat direkomendasikan dan digunakan oleh tenaga kesehatan dalam mendeteksi dini sehingga akan membantu penegakan diagnosa lebih cepat dan menentukan pengobatan secara lebih efektif.

\section{Ucapan Terima Kasih}

Saya ucapkan terima kasih kepada semua pihak yang membantu dalam terselesaikannya pengabdian ini, terutama kepada LPPM Institut Medistra Lubuk Pakam dan Rumah Sakit Grandmed Lubuk Pakam

\section{Daftar Pustaka}

Bakri Z; Hatta M; Nasrum M. 2010. Deteksi Keberadaan Bakteri Escherichia coli 0157:H7 pada Feses penderita diare dengan Metode Kultur dan PCR. JST Kesehatan; (5), 2:184-192

Brooks GF, Butel JS, Morse SA (2005). Mikrobiologi Kedokteran Jawetz, Melnick, dan Adelberg.
Edi Nugroho (alih bahasa). Jakarta : Salemba Medika

Dutta T.K., Roychoudhury S.P., Bandyopadhyay Wani S.A., and I. Hussain. (2011). Detection and characterization of Shiga toxin producing Escherichia coli (STEC) \& enteropathogenic Escherichia coli (EPEC) in poultry birds with diarrhoea. Indian J. Med. Res. Vol 133, hal: 541545.

Elliott $\mathrm{T}$, Worthington $\mathrm{T}$, Osman $\mathrm{H}$, Gill M (2013). Mikrobiologi Kedokteran \& Infeksi Edisi 4. Jakarta : EGC

Hermayudi dan Ayu, P.A. (2017). Penyakit daerah tropis. Yogyakarta: 2017.

Hidayatu W., Temaja I.G.R.M., dan Fatmawati N.N.D. (2018). Karakteristik Fenotip Isolat Klinik Escherichia coli O157:H7 Pada Media Sorbitol Mac Conkey Agar (SMAC). J. Agric.Sci. and Biotechnol. Vol 7 (1).

Jaipah N, Saraswati I, Hapsari R (2017). Uji Efektifitas Antimikroba Ekstrak Biji Pepaya (Carica Papaya L.) Terhadap Pertumbuhan Escherichia coli Secara In Vitro. Jurnal Kedokteran Diponegoro, ISSN : $2540-8844,6(2)$

Jawetz, M. A. (2010). Mikrobiologi Kedokteran. (25 ed). (G. F. Brooks, K. C. Carroll, J. S. Butel, S. A. Morse, T. A. Mietzner, Penyunt, A. W. Nugroho, D. Ramadhani, H. Santasa, N. Yasdelita, \& K. W. Nimala, penerj). New York: Mc Graw Hill.

Jayanti, D. D. (2018) 'Deteksi Escherichia colo O157 Pada berbagai Air Minum di Kelurahan Sekaran Gunung Pati Semarang'. Universitas Negeri Semarang

Morin NJ, Gong Z \& Li XF. 2004. Reverse Transcription-Multiplex PCR Assay for Simultaneous Detection of Escherichia coli O157: H7, Vibrio cholerae OI, and Salmonella Typhi. Clinical Chemistry. 50(11): 2037-2044. 
Received: 16 June 2021 :: Accepted: 25June 2021 :: Accepted: 30 June 2021

Peter C.H., Councell F.T., Keys C., and Monday S.R. (2011). Virulence characterization of Shigatoxigenic Escherichia coli isolates from wholesale produce. Appl. Environ. Microbiol. Vol 77 (1), hal: 343-345.

Rananda RM, Djamal A, Julizar. 2016. Identifikasi Bakteri Escherichia coli 0157:H7 dalam Daging Sapi yang Berasal Dari Rumah Potong Hewan Lubuk Buaya. Jurnal Kesehatan Andalas 5(3): 614617

Rizky, V. A. (2018) 'Perbedaan Jumlah Koloni Bakteri Escherichia coli Pada Penanaman Menggunakan Teknik Sengkelit (calibrated loop) dan Mikropipet (pipet dilution method) Metode Spread plate'. UKMC Palembang

Sartika, Indrawani, dan Sudiarti. (2005). Analisis Mikrobiologi Escherichia coli 0157:H7 Pada Hasil Olahan Hewan Sapi Dalam Proses Produksinya. Jurnal Makara Kesehatan, Vol 9 No (1), Hal 23-28.

Vos, P. et al. (2009). Bergey's Manual of Systematic Bacteriology. 2nd edn, Springer-Verlag New York. 2nd edn. Springer-Verlag New York. doi: 10.1007/978-0-38768489-5. 